\title{
PANDORINA SKRINJICA - GEOGRAFSKI POGLEDI NA PROSTORSKE ANALIZE V PLANIRANJU*
}

\author{
Andrej Černe \\ Oddelek za geografijo Filozofske fakultete Univerze v Ljubljani, \\ Aškerčeva cesta 2, SI - 1000, Ljubljana, Slovenija \\ e-pošta: andrej.cerne@guest.arnes.si \\ Kratki znanstveni prispevek \\ COBISS 1.03
}

\section{Izvleček}

Prostor je nujen kot zrak, ki ga dihamo, je prostor na katerem stojimo in po katerem hodimo ter se premikamo. Človek je s prostorom, je del prostora in ne more biti odsoten iz prostora. Če obstajamo, moramo biti nekje, to pa pomeni, da moramo biti z določenim prostorom. Prostor nas vedno obdaja. Živimo s prostorom, z njim smo v določenih razmerjih z ljudmi in z njim umremo. Članek prikazuje znotraj tega konteksta številne probleme, ki izhajajo iz analitičnega pristopa $\mathrm{k}$ vrednotenju različnih pomenov prostora.

Ključne besede: prostor, geografija, prostorske analize, prostorsko planiranje

\section{PANDORA'S BOX - GEOGRAPHICAL VIEWS OF THE SPATIAL ANALYSIS IN PLANNING}

\begin{abstract}
Space is a requisite as the air we breathe, the ground on which we stand, we walk over and through it. Human being is with space, he is part of space, he can not be absent form space. To be at all - to exist in any way - is to be somewhere, and to be somewhere is to be with some kind of space. We are always surrounded by space. We live with space, relate to others with it, die with it. Within this context article deals with the problems arising from analytical approach towards the evaluation of different meaning of space.
\end{abstract}

Key words: space, geography, spatial analysis, spatial planning

\footnotetext{
* Nastopno predavanje ob izvolitvi v naziv rednega profesorja za družbeno geografijo, 5. maja 2005 na Filozofski fakulteti v Ljubljani.
} 
Vsi več ali manj poznamo zgodbo o Pandorini skrinjici oziroma Pandori kot prvi umrljivi ženski, lepotici, ustvarjena ljudem v pogubo. Ustvaril jo je Hefajst, drugi bogovi pa so jo obdarovali: Atena ji je dala dušo, Afrodita lepoto, Zevs pa ji je podaril škatlico, v kateri so bile zaprte vse človeške tegobe in bridkosti, in ji zabičal, da je ne sme odpreti. Pandora je vsa radovedna pokukala vanjo, bridkosti so ji ušle in se razpasle med ljudmi. V škatlici je ostalo le upanje.

V mojem predavanju sem se $\mathrm{v}$ večji meri usmeril na vprašanja, kot pa na odgovore, torej na tegobe in izzive, saj so odgovori do katerih se lahko dokopljemo tudi s pomočjo geografije do neke mere naše upanje, ki ostaja v Pandorini skrinjici. Moj namen v tem predavanju ni dokazovanje predpostavk marveč odpiranje vprašanj, o katerih morda do sedaj nismo razmišljali na ta način, ter poskušati ta vprašanja tudi razumeti. Bolj kot odgovarjati želim torej postavljati vprašanja.

Tegobe izhajajo iz številnih in različnih razprav o prostoru, vidikov in obrazov prostora, pomenov, ki jih pripisujemo prostoru, pristopov $\mathrm{k}$ analizam prostora in nenazadnje tudi različnih teorij prostora. Tegobe izhajajo že iz samega razmeroma ohlapnega razumevanja pojma prostora, zato je izredno težko, če ne celo nemogoče razvijati kakršno koli jasne koncepte o tem, kaj mislimo z besedo prostor. Do katere mere lahko prostor razumemo oziroma dojamemo njegov pomen? Ali različne stroke, ki obravnavajo prostor, $\mathrm{v}$ resnici govorijo o enakih »stvareh «?

Pojem prostora je opredeljen s številnih zornih kotov: geografije, filozofije, fizike, epistemologije, ekologije, geopolitike, antropologije, etnologije, arhitekture, krajinske arhitekture, planiranja itd. Opravka imamo z geografskim, arhitekturnim, krajinskim, etnološkim, demografskim prostorom, prostorom informacijske znanosti itd. Arhitekti so povezani $\mathrm{z}$ arhitekturnim prostorom, ekonomisti si prilaščajo gospodarski prostor, geografi pokrajine in regije. Govorimo o slikarskih, glasbenih ali kiparskih prostorih in tako v neskončnost. Prostor izražamo in vrednotimo v znanstvenem, geografskem, socialnem, ekonomskem, planerskem, poetičnem, mističnem, instrumentalnem, moralnem in etičnem, ter čustvenem in efektivnem jeziku. Prostor opredeljujemo na konkreten pa tudi na abstrakten, simbolni način.

Prostor ima nešteto obrazov in vidikov oziroma, bolje rečeno, ima vse možne obraze in vse možne vidike. Zato so možne različne analize oziroma bolje vse analize. Koliko in katere analize potrebujemo, da opišemo prostor oziroma pokrajino kot celoto. Poleg tega pa je podoba, ki se zrcali iz prostora samo ena izmed možnih podob, saj lahko v prostor vstopamo na različne načine oziroma na vse možne načine.

Prostora ne proučujemo samo kot fizični pojem, marveč tudi kot stvarnost, ki se lahko čuti in doživi. Zaznavanje prostora se povezuje s psihologijo, psihofiziologijo, estetsko prakso, lingvistiko itd. Za estetske vidike prostora ne poznamo drugačnega kot subjektivnega pristopa. Kot estetsko kategorijo je mogoče prostor razmeroma preprosto določiti, saj ga lahko označimo za vrednoto, ki nam posreduje specifična ugodja. Velik del pomenov prostora leži izven znanosti. Rimski duh kraja (genius loci), Humboltova »fiziognomija«, Bensonova »duša«, Volzov »ritem«, Gradmannova »harmonija«, Bachelardova »poetika prostora« itd. ležijo onkraj znanosti. Nekateri verjamejo, da obstaja poleg širšega opazovanja in marljivega risanja še kakovostni način razumevanja prostora na višji ravni, ki pa ga ne moremo skrčiti na formalne procese. 
Zanimivo je, da krajina prvotno sploh ni bila prostorski pojem, marveč ekonomski oziroma gospodarski, saj je pomenila v srednjem veku v Angliji ozemlje, ki je pripadalo lordu oziroma, ki je bilo poseljeno z določeno skupino ljudi.... Tudi kasneje je bila povezana $\mathrm{z}$ umetniškim upodabljanjem. V zgodnjem 17. stoletju se je pojem pod vplivom nizozemskih »landshap« slikarjev nanašal na zunanji videz območja, in sicer bolj natančno na reprezentacijo scene (slike pokrajine, pejsaža); izvor besede: holandski landschap, iz land in schap - ladija; slika ki predstavlja pogled naravne kopne pokrajine; Šele ob koncu 19. stoletja pa je postala tudi prostorski pojem, saj se je pojem uporabil za opredelitev dela zemljišča, oziroma ozemlja, ki ga lahko zaobjame oko z enim pogledom, vključno z vsemi objekti, ki jih tako vidimo, posebno v njihovem slikovitem vidiku.

O svojstvenem načinu opredeljevanja prostora govori tudi zgodba o tem, kako je imel Sokratov filozof Aristippus brodolom (Vitruvius je tako zapisal v predgovoru k šestemu zvezku De architectura), ko se je rešil na obalo Rodosa. Tam je zagledal tri geometrične like narisane v pesek, in rekel svojim kolegom: »Imam dobro novico, saj v resnici vidim sledove človeka« (Glacken, 1967, str. I). Obstajata pravzaprav dve temeljni teoriji prostora relacijska in substancialna. Klasična teorija prostora govori o tem, da je prostor kontinuirana razsežnost oziroma, da je prostor neodvisen od katerekoli substance, ki zaseda prostor. $\mathrm{Na}$ eni strani govorimo o prostoru kot neke vrste prvotne snovi (materije), ki se nanaša predvsem na obseg (razsežnost) posameznih fizičnih stvari in je sestavni element določenega telesa. Drugo razumevanje se nanaša na trditev, da prostoru ne bi smeli pripisovati kakršne koli ločene stvarnosti, marveč bi ga morali razumeti kot vsoto vseh urejenih razmerij, ki obstajajo med fizičnimi entitetami. Če govorimo o stvareh v prostoru gre za stališče, da je prostor »posoda«, »okvir« v katerem so stvari razporejene, v katerega nameščamo stvari, v katerega posegamo itd.

Platon je bil mnenja, da prostor ni ustvarjen, čas pa je. Prostor naj bi namreč obstajal že pred stvarjenjem časa in sveta, in sicer kot nek pra-prostor, kot »posoda stvarjenja«, ki jo je Platon imenoval hora. Grki niso imeli samo ene besede, ki bi bila enakovredna današnji besedi prostor. Glavna prostorska pojma sta bila hora in topos. Prvi se je nanašal na razsežnost (obseg), medtem ko je bila relativna lokacija izražena s pojmom topos (Keimpe, 1997, str. 33). Leibniz je zagovarjal relacijsko teorijo, saj je bil menja, da prostor biva le v spletu razmerij med stvarmi. »...to, kar vsebuje vsa mesta (stvari), imenujemo prostor.... « zagovarjal je tezo, da je ves prostor poln in da praznina ne obstaja; praznina ne samo da ni po ničemer določljiva, saj nekaj, česar ni, ne more biti v odnosu $\mathrm{z}$ nečim, kar je, namreč $\mathrm{s}$ stvarmi. Stvari so lahko v medsebojnih razmerjih, ker je med njimi prostor, ne pa ničesar. In stvari dejansko so v medsebojnih razmerjih, zato med njimi ni praznine (Leibniz, 1979).

Zanimivo je stališče francoskega filozofa Gassendija: » Prostor kot celota je neomejen, nima ne začetka ne konca; vsak del prostora je v vseh časih isti (trajen)... ostaja negiben, bodisi da v njem kaj obstaja ali ne... ne more ga premakniti nobena moč, saj ostaja nespremenljivo neprekinjen in vselej isti; .... ko govorimo o prostoru, rečemo povsod ali nekje, ... Bitja so samo nekje, z ozirom na prostor in samo včasih, z ozirom na čas... " (Uršič, 2002 , str. 228,229)

Newton je zagovarjal substancionalno teorijo prostora. » ...Absolutni prostor ostaja vselej isti in je negiben po svoji lastni naravi, je brez odnosa do česarkoli izven sebe. Rela- 
tivni prostor je neka gibljiva razsežnost ali merilo absolutnih prostorov, ki ga naši čuti določijo s svojim položajem do teles in katerega najpogosteje smatramo za negibnega.... Absolutni in relativni prostor sta enaka po podobi..... (Newton, 1962, str. 8).

Tudi Kant je zagovarjal substancialno teorijo, saj je bil prepričan, da prostor obstaja neodvisno od predmetov v njem. Dokazovati je poskušal absolutnost prostora oziroma obstoj samega prostora, torej neodvisnost od česarkoli v njem. Prostor naj bi določale lastnosti predmetov v njem, zato naj bi prostor obstajal neodvisno od njih. Bil je prepričan, da prostor »kot tak« obstaja (Kant, 1993). Geografija vidi prostor kot pokrajino, in ker je pokrajina rezultat razmerij med različnimi dejavniki, ki so prispevali k ustvarjanju pokrajine, se zavzemam predvsem za relacijsko teorijo prostora. S pojmom pokrajina opišemo tiste lastnosti in značilnosti prostora ki vplivajo na prostor na tak način, da prostor je pokrajina. Lastnost pokrajine je tisto, kar jo opredeljuje, da je to, kar je, značilnost pa je lastnost značilnega, torej tistega, kar pokrajino določa tako, da jo je mogoče razpoznati, ločiti od drugega prostora. Strabo, avtor 17. knjig s področja geografije, sicer ni pisal o tem, kaj je prostor, je pa poskušal opredeliti kaj je temeljna naloga geografa. Bil je mnenja, da je geograf oseba, ki poskuša opisati dele zemlje. Opredelil je pravzaprav tisto, kar danes imenujemo regionalna geografija. Strabov koncept je uporabil Ptolomej pri geografiji kot vedi, ki poskuša zasnovati pogled na celoto. Geografijo je ločil od vede o stvareh v prostoru, saj je bil mnenja, da horologija opisuje samo dele, ne pa celote. To je primerjal s slikarjevim risanjem ušesa ali očesa, ne pa cele človeške glave (Černe, . Hartschorne je v knjigi Značaj geografije zapisal: » Geografija je zadolžena za pripravo natančnih, urejenih in racionalnih opisov in interpretacij spremenljivih značilnosti oziroma potez zemeljskega površja...." (Hartschorne, 1993, str. 56). Primer opisne geografije ima svoje korenine v nemški geografiji, posebno v idejah Alfred Hettnerja. ki je geografijo imel za regionalno-opisno disciplino. Za Hartshorna je geografija veda, ki proučuje območja in kraje na zemeljskem površju z vidika njihovih razlik in njihovih prostorskih razmerij.

Nadaljnja tegobe izhajajo tudi iz samega planerskega konteksta, ki se nanaša na oblikovanje različnih stopenj priprave prostorskih dokumentov od politike, analize in ocene stanja in razvojnih teženj, zasnove vizij in konceptov ter strategij do izvajanja in monitoringa. Geddes, škotski biolog, oče regionalnega planiranja, regionalnega mesta in biopolisa, je $\mathrm{v}$ regionalnem planiranju utemeljeval planerski koncept zasnovan na podlagi »analize pred planom«, ideje, ki je prišla iz nemških strokovnih krogov. Bil je zagovornik treh temeljnih strokovnih korakov v planiranju: analiza, ekspertiza, plan. Analiza je neposredna podlaga za načrtovanje prostorskega razvoja, vprašanje pa je, katere in kakšne analize potrebujemo, da bi lahko opredelili oziroma ocenili stanje, razmere, značilnosti in lastnosti prostora, ki bodo neposredna podlaga za načrtovanje prostorskega razvoja? Razvoj je vsekakor nekaj kar načrtujemo tudi s prostorom, vprašanje pa je, kaj je predmet načrtovanja prostorskega razvoja: prostorsko razporejanje dejavnosti, raba zemljišč, prostorski vidiki gospodarskega in socialnega razvoja itd. Ali planiramo razvoj v prostoru ali s prostorom? Ali planiramo fizično stvarnost oziroma snovni svet in zato potrebujemo analizo fizične stvarnosti, in sicer take kot je ali take kot jo zaznavamo, vidimo, doživljamo, izkušamo in razumemo. Ali načrtujemo ves razvoj v prostoru? Ali naj analiziramo stvari v prostoru ali prostor sam po sebi? Ali naj bodo analize zasnovane na podlagi vsakokratnih potreb glede tako imenova- 
nega poseganja v prostor, enkrat za avtoceste, enkrat za poselitev, enkrat za lokacijo dejavnosti itd., ali naj bodo analize narejene na podlagi stvarnih prostorskih razmer in pogojev ter njihovega vrednotenja?

Temeljno vprašanje je seveda, koliko analiz potrebujemo, da lahko opredelimo stanje prostora? Ali potrebujemo vse analize oziroma analize vsega kar je v prostoru, ali samo najpomembnejše prostorske analize oziroma tiste, ki dajejo neposredno podlago za planiranje prostorskega razvoja? Na katere prostorske razmere, značilnosti in lastnosti moramo biti pozorni oziroma na katere dele prostora moramo usmeriti našo pozornost?

Z geografskega vidika bi lahko zagovarjali stališče, da je predmet analize sistem razmerij v stvarnem fizičnem prostoru, ki ima svoje naravne (fizične, fizikalne, kemijske, biološke) značilnosti ter značilnosti, ki jih je ustvaril človek oziroma tudi značilnosti, ki mu jih pripisuje človek. Besedo prostor uporabljamo v njenem najširšem pomenu, saj ni omejena samo na trodimenzionalno evklidovo geometrijo, marveč se nanaša tudi na zgodovinski, gospodarski, psihološki in zaznavni ter estetski prostor.Osrednji predmet prostorskega planiranja je izrazito prostorski. Prostor kot fizična stvarnost je materialni predmet planiranja. Pojem prostor uporabljamo v njenem najširšem pomenu, saj ni omejen samo na trodimenzionalno geometrijo, marveč se nanaša tudi na ekonomski ali psihološki in zaznavni prostor. Prostor je najpogosteje izražen v obliki zemeljskega površja. Ne pomeni prostora $\mathrm{v}$ smislu zunanjega prostora (vesolja) niti prostora v smislu urejenih stvari v vrsti. Odločanje o »posegih v prostor« pa je formalni predmet planiranja. Končni namen planiranja je seveda $\mathrm{v}$ vplivanju na spremembe materialnega predmeta - prostora. Ne glede na to, kako je lahko stvarni prostor popačen zaradi ekonomskih ali psiholoških dejavnikov mora biti osrednji predmet zanimanja prostorskih planerjev proučevanje medsebojnih prostorskih razmerij v stvarnem fizičnem prostoru. S prostorskega vidika je temeljnega pomena to, da ima razvoj prostorsko komponento oziroma razsežnost. Poudarjanje pozornosti na formalni predmet planiranja je temeljni korak pri planiranju. Predmet analize je prostorska stvarnost kot prostorska struktura. Pri tem se moramo zavedati, da obstaja razlika med stvarno podobo in videzom prostorske strukture, med vsakdanjim in znanstvenim pojmom prostorske stvarnosti. Prostorsko planiranje se ukvarja torej z vprašanji prostorskega nameščanja razvoja, ne s splošnim preprečevanjem tega razvoja, vendar ob spoznanju, da ima prostor omejene sposobnosti za nameščanje razvoja kot rasti. Bilo bi zelo nevarno, če bi se prostorsko planiranje ločilo oziroma odmaknilo od razvojnih interesov.

Analize so pomembne zaradi tega, ker ljudje živijo s prostorom. Ljudje niso abstraktna kategorija dela, ki se gibljejo iz kraja v kraj oziroma v tista območja, ki trenutno kažejo gospodarski razcvet. V načelu so sicer prebivalci lahko tako mobilni, kot jih predvidevajo številni razvojni modeli. Vendar pa so ljudje socialna bitja, ki žive v družinah, gospodinjstvih in skupnostih, ki so v medsebojnih odnosih s sosedi, sorodniki, prijatelji in družinami. $\mathrm{V}$ določenem času se ljudje naselijo v določenih krajih in razvijejo določen vzorec govora, navad, družbene prakse, s katerimi se poistovetijo in se počutijo »doma«. Ljudje imajo tudi lokalne in regionalne vezi, ki jih vežejo na določena območja, posebno velja to za starejše skupine ljudi. Take skupine ljudi se nerade selijo, ko pa se, je to zelo boleč proces. Zato moramo na prostorsko primerni ravni analizirati prevladujoče pogoje življenja in bivanja. 
Analize se nanašajo na relevantne razmere in pogoje, zato se lahko nanašajo seveda na številne in različne oziroma vse možne analize, in sicer na vseh prostorskih ravneh: na državni, regionalni in lokalni ravni oziroma poljudni prostorski ravni, in sicer na iskanje dejstev o prostoru ali spoznanj o dejstvih, analizo problemov, pretresanje obstoječih razmer, oceno okolja, analizo ustreznih pogojev ali informacijsko podlago, analizo rabe zemljišč itd. Zato je potrebno določiti področja in območja analiz. Vedeti moramo, kakšen pojav moramo proučevati, katera vprašanja si moramo zastavljati in, kakšna filozofska stališča morajo usmerjati naše raziskave. Analiza kot taka potrebuje omejitve in samo konceptualna definicija lahko take omejitve tudi omogoča, saj se prostorski koncepti nanašajo na prostorsko razporeditev, prostorsko integracijo, medsebojne prostorske vplive in prostorske procese. Vse to pa se nanaša na ekosistem, katerega pomemben sestavni del je človek. Pri analizi je zato potrebno oblikovati jasna načela, izhodišča in cilje na podlagi katerih je možno nedvoumno prepoznavati prostorske razmere in sprejemati ustrezne odločitve za njihovo reševanje $v$ skladu $\mathrm{z}$ dolgoročnimi cilji prostorskega razvoja.

Pri tem je znanje o prostoru več ali manj razpeto med opisom prostora in njegovo členitvijo. Najpogosteje gre za opis stvari v prostoru ali posameznih delov prostora. Pri opisu gre najpogosteje za opisovanje tistega kar v prostoru je, pri členitvi pa tudi za poskuse opredeljevanja pomena posameznih sestavnih delov prostora. Ti posamezni deli prostora so izrezani iz prostora kot celote zaradi analize njegovih posameznih sestavnih delov.

Fragmentacija prostora sovpada $\mathrm{z}$ opredeljevanjem prostora $\mathrm{v}$ izredno raznovrstne prostore: stanovanja, kmetijstva, gozdarstva, industrije, rekreacije, turizma, itd. Več ali manj je jasno o čem govorimo, ko govorimo o stanovanju, vogalu ulice, tržnici, nakupovalnemu ali kulturnemu središču, javnemu prostoru itd. S temi pojmi na splošno opisujemo prostor, nanašajo pa se na določene specifične rabe prostora. $\mathrm{S}$ tem se pozornost usmerja na tisto kar v prostoru obstaja in s tem na ločevanje prostora od tistega kar je. Če znanje o prostoru nadomestimo $\mathrm{z}$ znanjem o stvareh razporejenih $\mathrm{v}$ prostoru, to pomeni, da dobiva naštevanje in opisovanje stvari v prostoru osrednji pomen. Na ta način so analize namenjene preštevanju stvari, različnih predmetov in objektov, ki so $\mathrm{v}$ prostoru. Zato je prostor pogosto obravnavan kot posamezna sestavina, element ali predmet med številnimi ločenimi sestavinami, elementi in predmeti v pokrajini. Omejevanje zgolj na eno področje oziroma vsebinsko poenostavljanje tistega kar prostor je, lahko hitro preide $\mathrm{v}$ redukcionizem, $\mathrm{v}$ enostransko, ozko obravnavo in razlago vsebin. Specializacija lahko vpliva na drobljenje prostora med različne vede.

$Z$ vidika tega, kaj analiziramo naj omenimo še en vidik tegob, ki se nanaša na zaznavanje prostora. Odločitve, ki jih sprejemamo glede načrtovanja prostora, so zasnovane $\mathrm{s}$ prostorom kot ga zaznavamo, in ne s prostorom kakršen je. Ukrepi, ki sledijo odločitvam pa se na drugi strani odvijajo s stvarnim prostorom in vplivajo na stvarne prostorske razmere.

Zaznava prostora nam nudi namreč eksplicitna dejstva o tem, kaj je prisotno v prostoru, implicitna znanja o tem kako vzajemno delovati s prostorom in nas oskrbi s subjektivno zaznavnim občutkom (izkustvom). Zaznava prinaša opazovalcu dve stvari (eksplicitno in implicitno) spoznanje in subjektivno izkustvo. (Booth, 2002).

Najpogosteje je oko tisto, ki nas vodi k spoznavanju prostora. Prostora pa ne zaznavamo oziroma gledamo, samo z očmi. Poleg tega pa ga gledamo seveda z možgani, in ne 
samo s sistemom vidnega čuta. Prostora ne zaznavamo samo na podlagi vizualnih, optičnih »informacij«, marveč tudi na podlagi preostalih štirih čutov: sluh, glas, vonj (okus) in otip.

Ko gledamo oljko, svetloba, ki odseva od nje oblikuje podobo oljke na naši očesni mrežnici. Fotosenzitivne celice $\mathrm{v}$ mrežnici aktivirajo elektrone in sprožijo elektrokemične impulze. Ti odpotujejo po vidnem živcu v središče za vid v možganih, kjer so podatki izpostavljeni kompleksni obdelavi, ki razkrije oblike, vzorce, barve in gibe. Možgani nato strnejo te podatke v skladno celoto in oblikujejo svojo rekonstrukcijo zunanjega fizičnega sveta. Nazadnje se podoba oljke pojavi v naši zavesti. Čeprav sploh ne vemo, kako se podoba pojavi v umu, se zgodi. Doživljamo zavestno izkustvo videnja oljke.

Vse, kar zaznavamo - vse kar vidimo, slišimo, okušamo, vonjamo in česar se dotikamo, je preoblikovano iz čutnih podatkov. Prepričani smo, da zaznavamo prostor okoli sebe, toda, vse na kar smo neposredno pozorni, so barve, oblike, zvoki in vonji, ki se pojavljajo v umu. Barve in zvoki, ki jih izkušamo, v resnici niso »zunaj« v prostoru, marveč so vse podobe uma, slika, podoba stvarnega fizičnega prostora, ki smo jo zgradili.

Naša podoba prostora temelji torej na čutilnih podatkih, črpanih iz fizičnega prostora, oziroma snovnega sveta, ki temelji na predpostavki, da so prostor, čas, snov in energija temeljne sestavine stvarnosti. Znanost izjemno uspešno pojasnjuje zgradbo in delovanje fizičnega oziroma snovnega sveta, toda ko se približa področju uma - mislim, občutkom, čutenju, intuiciji in sanjam - se pojavijo številne nejasnosti. Problem je torej z zavestjo, ki ni sestavljena iz snovi, saj je temeljna predpostavka znanosti, da snov nima zavesti. Vprašanje je seveda, kako lahko nesnovna zavest nastane iz nezavedne snovi? Težava pri iskanju odgovora na to vprašanje izhaja predvsem iz predpostavke, da zavest vznika iz snovnega sveta prostora, časa in snovi ali je celo odvisna od njega. Druga predpostavka pa je, da zavest ne nastane iz neke posebne ureditve živčnih celic ali procesov, ki potekajo med njimi, ali iz drugih fizikalnih lastnosti, marveč je vedno navzoča. Stališče, da zavest v vsem izhaja iz prepričanja, da se sposobnost za notranje izkustvo ne more razviti ali pojaviti iz popolnoma nezavedne snovi, ki nima izkustev. Izkustvo lahko vznikne le iz nečesa, kar že ima izkustvo. Prepričani smo, da fizična stvarnost prostora zares obstaja. Mogoče tega ne vemo neposredno, verjamemo pa, da je tako. Fizična stvarnost prostora pa ni nekaj, kar si predstavljamo, da je (Russell, 1993). Ideja, da je zavest v vsem, se v filozofskih krogih imenuje panpsihizem, iz grške besede pan, ki pomeni vse in psyche, ki pomeni dušo ali um. Sodobni filozofi uporabljajo tudi izraz paneksperientalizem - vse ima izkustvo (Casey, 1997).

V stvarnem fizičnem prostoru vidimo pravzaprav tisto česar ni (Boothe, 2002). Podoba prostora, ki se nam kaže v umu, se pomembneje razlikuje od stvarnega fizičnega prostora, in sicer z dveh pomembnih vidikov (Alegria, 1983):

- $\quad$ podobe prostora presegajo fizično stvarnost, saj vsebujejo številne lastnosti, ki jih v fizični resničnosti ni: npr. barve. V fizičnem svetu obstaja svetloba različnih frekvenc, vendar svetloba sama po sebi ni rumena, kot niso rumeni električni impulzi, ki jih oko odpošlje v možgane. Rumena, ki jo vidimo, je lastnost, ustvarjena v zavesti in obstaja kot subjektivno izkustvo uma. Podobno velja tudi za zvok. Ali drevo, ki pade, odda zvok, če ni zraven nikogar, ki ga bi slišal. Odgovor je »ne«. V fizični stvarnosti ni nobenega zvoka, so le valovi pritiska v zraku. Zvok obstaja le kot izkustvo v umu tistega, ki ga zaznava; 
- fizična stvarnost prostora presega naše podobe, saj obstajajo v prostoru številni vidiki, ki jih nikoli ne izkusimo. Naše oči so npr. občutljive le za svetlobo v ozkem frekvenčnem pasu od 430.000 do 750.000 gigahertzov (gigahertz = milijarda nihajev na sekundo). Nižjih in višjih frekvencah naše oči ne zaznavajo, zato predstavlja naša vidna podoba fizične stvarnosti le droben delec prostora. Enako velja tudi za druga čutila. Kar slišimo, vohamo in okušamo je le omejen del fizične stvarnosti. Nekateri vidiki fizičnega sveta (magnetna polja in električni naboji) imajo poleg tega majhen, če sploh kakšen vpliv na naše doživljanje.

Več ali manj sprejemamo stališče, da je prostor, ki nas obdaja, sestavljen iz snovi. Stvarni fizični prostor, ki ga zaznavamo, pa seveda ni samo fizični svet. Prostor, ki ga poznamo, je prostor ki se oblikuje $\mathrm{v}$ našem umu, zato ta prostor ni narejen iz snovi, marveč iz umskega gradiva. Vse, kar poznamo, zaznavamo in si predstavljamo, vsaka barva, zvok, občutek, misel in občutenje, je oblika, ki jo je prevzela zavest (Boothe, 2002).

Nedvoumno lahko sklepamo torej, da neposredno zaznavamo stvarni fizični prostor. Čeprav je izkustven svet zgradba znotraj uma, prostor še vedno vidimo »zunaj«, okoli nas. Pet stoletij po Koperniku, še vedno vidimo, kako Sonce zahaja, čeprav vemo, da se v resnici vrti Zemlja.

Na podlagi razprave lahko $\mathrm{v}$ sklepnih ugotovitvah opredelimo tista izhodišča, znotraj katerih moramo tudi geografi pristopati k spoznavanju in razumevanju prostora:

- Človek je s prostorom, je del prostora in ne more biti odsoten iz prostora. Človek je vedno s prostorom ter različnimi možnimi načini uravnavanja razmerij s prostorom. Ko človek biva, biva s prostorom in je tudi izpostavljen določenim prostorskim vplivom. S prostorom živimo, prostor zaznavamo in prostor si predstavljamo. Prostor s katerim živimo je nekaj drugega kot prostor, ki ga proučujemo, o katerem razmišljamo, ga doživljamo in občutimo ter prostor, ki si ga predstavljamo. Razmerja med življenjem s prostorom in predstavljanjem ter zaznavanjem prostora nikoli niso preprosta ali stalna.

- Prostor govori o procesih, ki so ga oblikovali, o življenju tistih, ki so ga poselili in preoblikovali.

- Obstajajo različni prostori, ki pomenijo območja razlik in drugačnosti, raznovrstnosti vrednot in življenjskih možnosti. Pri prostoru gre za upoštevanje različnosti prostora, družb, ekosistemov in kultur. Gre za pluralnost različnih prostorov in ne za en vseobsegajoči »super« prostor. Koncept različnosti in raznolikosti prostora temelji na razumevanju različnih načinov življenja in bivanja $\mathrm{z}$ različnimi pogoji in $\mathrm{z}$ različnimi prostorskimi in ostalimi možnostmi. Vsaka družba ustvarja lasten prostor in s tem vpliva na nastajanje različnih prostorov. Vsako mesto, kraj, regija ustvarja lasten prostor.

- Nova tehnična in tehnološka ter znanstvena moč človeka vpliva na spreminjanje prostora. Fizični, naravni prostor počasi izginja, čeprav ni popolnoma izginil. Posamezni deli prostora so vedno bolj vredni, saj dobivajo simbolno težo in pomen. Vsak želi varovati in zaščititi prostor: nihče noče zmanjševati njegove avtentičnosti. Istočasno pa je vse usmerjeno $\mathrm{k}$ njegovemu preoblikovanju.

- V prostoru je vedno prisotno prej in potem, medtem ko sedanjost prevladuje nad preteklostjo in prihodnostjo. Sv. Avguštin je bil mnenja, da vsi trije časi - preteklost, sedan- 
jost in prihodnost - bivajo le $\mathrm{v}$ duši. Ker pa duša na tem svetu biva le $\mathrm{v}$ sedanjosti in je zavestno prisotna tu-in-zdaj, so ti časi le trije načini sedanjosti, ki izhajajo iz treh osnovnih duševnih funkcij: spomina, vpogleda in pričakovanja. »Sedanjost glede preteklosti je spomin, sedanjost glede sedanjosti je vpogled, sedanjost glede prihodnosti je pričakovanje« (Uršič, 2002, str. 268). Iz zgodovine filozofije je dobro poznan naslednji argument: tistega, kar je preteklo, po definiciji ni več, tistega, kar je prihodnje, pa po definiciji še ni. Toda doživljanje časa je vendarle proces, $v$ katerem je to, kar je bilo in to kar pričakujemo, da bo, občuteno kot resnično. S tega vidika je spoznanje o sedanjosti preteklosti popolnoma nekaj drugega, kot pa sedanjost prihodnosti, saj prihodnosti še ni. Čas je prisoten v pokrajini in ga vidimo povsod kot pretekli čas, saj je vsa pokrajina na nek način rezultat preteklosti.

- Prostor ni prazen in nevtralen prostor, ki je napolnjen s stvarmi, marveč je kot neko polje različnih razmerij, poln napetosti in neprestanih sprememb. Prostor je notranje raznolika dialektična in dinamična oblika relativne »trajnosti«, podvržen neprestanim in vedno hitrejšim spremembam.

- Prostor je zibelka, rojstni kraj in medij komuniciranja narave $\mathrm{z}$ družbo in družbe z naravo, zato je prostor vedno poln antagonizmov in/ali harmonij.

In naj za konec še enkrat navedem Sv. Avguština: »Ljudje potujejo, da bi se čudili višini gora, velikanskim valovom morja, dolgim tokovom rek, prostranosti oceana, kroženju zvezd; in stopajo mimo sebe, ne da bi se čudili«.

\section{Literatura in viri}

Alegria, J., 1983. Prostor i vreme danas. Nolit, Beograd.

Boothe, R. G., 2002. Perception of the Visual Environment. Springer-Verlag, New York.

Casey, E. S.,1997. The Fate of Place. A Phylosophical Hystory. University of California Press, London.

Černe, A., 2004. Analiza pred planom. Prostorske znanosti za 21. stoletje. Fakulteta za gradbeništvo in geodezijo, Interdisciplinarni podiplomski študij prostorskega in urbanističnega planiranja, Ljubljana, str. $31-40$.

Černe, A., 1999. Prostorska identiteta - koncept različnosti. Anthropos, Časopis za psihologijo in filozofijo ter za sodelovanje humanističnih ved, Letnik 31, štev. 4-6, str. 296-300, 4 cit. lit.

Glacken C. J., 1967. Traces on the Rhodian Shore. Nature and Culture in Western Thought from Ancient Times to the End of the Eighteen Century. University of California Press, Barkley.

Hartshorne, R., 1939. The Nature of Geography: Association of American Geographers, Lan-caster, Pennsilvania.

Kant, I., 1993. Kritika čistega uma. Analaecta, Ljubljana.

Keimpe, A., 1995. Concepts of Space in Greek Thought. Brill, E. J. Leiden.

Leibniz, G. W., 1979. Izbrani filozofski spisi. Slovenska matica, Ljubljana. 
Newton, I., 1962. Mathematical Principles of Natural Philosophy. University of California Press, Barkeley.

Russell, P., 1993. Sedaj. Konec časa in začetek sedanjosti. Alpha Center, Ljubljana.

Uršič, M., 2002. Štirje časi. Filozofski pogovori in samogovori. Pomlad. Prvi čas. Cankarjeva založba, Ljubljana. 